\begin{tabular}{c} 
Volume and Issues Obtainable at Center for Sustainability Research and Consultancy \\
Journal of Accounting and Finance in Emerging Economies \\
ISSN: 2519-0318 ISSN (E) 2518-8488 \\
Volume 4: Issue 1 June 2018 \\
CSRᄃ \\
Journal homepage: www.publishing.globalcsrc.org/jafee \\
\hline
\end{tabular}

\title{
Impact of Leverage and Risk Exposure on Financial Performance in SMEs of Northern Punjab
}

\section{${ }^{1}$ Javed Iqbal , ${ }^{2}$ Muhammad Hamza Javed , 3Zubair Ahmad, ${ }^{4}$ Moeed Ahmad, ${ }^{5}$ Waris Ali}

${ }^{1}$ Lecturer at IMS, Bahauddin Zakariya University, Pakistan. javediqbal@bzu.edu.pk

${ }^{2}$ MS Scholar at DBA, Bahauddin Zakariya University, Sub Campus Sahiwal pakistan mhamzajaved@yahoo.com

${ }^{3}$ Assistant Professor at IMS, Bahauddin Zakariya University, Pakistan zubairahmad@bzu.edu.pk

${ }^{4}$ Assistant Professor at IMS, Bahauddin Zakariya University,Pakistan moeed.sandhu@bzu.edu.pk

${ }^{5}$ Research Assistant Professor at DBA, University of Sahiwal, Pakistan waris.ali@bzu.edu.pk

\section{ARTICLE DETAILS}

History

Revised format: May 2018

Available online: June 2018

\section{Keywords}

Leverage, Risk Exposure,

Profitability, Small Enterprises,

Medium Enterprises and

Commercial Sector

Organizations.

JEL Classification:

G32,L30,F13

\begin{abstract}
Basic objective of this research was to discover the impact of Leverage on

Risk and Profitability. For this purpose main focus of research was SMEs and Commercial sector of Pakistan. Leverage has three types DOL, DFL and DTL. And these three types of leverage are independent variables for this research while dependent variables of this research are ROE, ROA, ROS, GM and Risk. Further sales growth is also used as control variable in this research. Time frame for data analysis was 3 years from 2012 to 2014. Sample size for this research is 61 SMEs and Commercial sector organizations.

Secondary data was used in this research and data was collected by using different data collection methods. SPSS version 20 was used to analyze data. Linear regression analyses were used to check the significant relationship between independent variables and dependent variables.

This research is limited to just SMEs and Commercial sector organization so we cannot use these results for overall industry or sectors. This research is entirely new research for SMEs and Commercial sector organizations.
\end{abstract}

(C) 2018 The authors, under a Creative Commons AttributionNonCommercial 4.0

Corresponding author's email address: javediqbal@ bzu.edu.pk

Recommended citation: Iqbal, J. Javed, M.H., Ahmad, Z., Ahmad, M. Ali, W. (2018). Impact of Leverage and Risk Exposure on Financial Performance in SMEs of Northern Punjab. Journal of Accounting and Finance in Emerging Economies, 4(1) 17-28

DOI: $10.26710 /$ jafee.v4i1.356

\section{Introduction}

Organizations can finance their investments by using equity or debt and sometimes both equity as well as debt. Preference shares could also be used by a company. Companies' interest rate is fixed regardless rate of return on assets and preference dividend rate is too fixed. Every company is legally obliged to pay interest amount on debts. Common shareholders receive their income after the payment of all interests, taxes and preferred dividend. In businesses, leverage could be referred as use of minor investment or small volume of borrowed money to attain superior profits (Panday, 2010). This paper examined the relation between leverage, risk exposure and profitability. Purpose of this paper is to find the influence of leverage on risk exposure and profitability of SMEs and Commercial sector organizations. Leverage could be define as use of borrowed money in business to generate more profit. Company's measures their leverage by using leverage ratios. These measurements specify the use of fund obtained by lenders and 
owners. There are basically three classifications of leverage, first is degree of financial leverage, second is degree of operating leverage and third one is degree of combined leverage. Financial leverage could be define as a degree to which a commercial or depositor is spending the rented money. Financial leverage is an amount of how far firm practices debt and equity to back its moneys. Operating leverage could be defined as the use of large amount of fixed cost to variable cost in organizations operations or we can say use of fixed operating cost for operation of firm to generate more profit. While total leverage (DTL) could be define as a summarized effect of both DFL and DOL on organizations profitability. Risk exposure is all about the amount of risk a person, entity or organization is facing. The potential of loss occurrence in our chosen action is risk, or we can say chances of uncertain events occurrence in future. Though, in business, risk could be define as uncertainty about returns on investments. Or we say that risk is conceivable when companies' actual return on investment is different from the expected return on investment. But there is existence of an important concept, a business investment that shows greater level of risk it gives greater level of returns. Risk has some types: Financial risk, Price risk, Interest rate risk, Liquidity risk, Business risk, Market risk and Default risk. Profitability in common terms could be defined as the ability of any firm or business to generate profit. Profit is an amount that we left after paying all expenses from revenue of a business. Organizations measure their profitability by using different profitability ratios. These ratios determine either organization is going in profit or loss. If they are in profit then how much time it will take to payback their debts. These profitability measures also make organizations clever to develop their future strategies. If ratios show that organizations are not in profit, then it indicates that current strategies are not suitable, and there is a need to make some new strategies or make some amendments in previous strategies. Profit is final productivity for any organization if organization is not producing good profits then it has no future. It is a responsibility of financial manager to appraise profitability of firms regularly. And it is possible by computing profitability ratios (Panday, 2010). There are many profitability ratios. In this research researcher has used four profitability ratios to check the impact of leverage on level of profitability Return on Equity, Return on Sale, Return on Assets and Gross Margin.

\section{Literature Review}

According to earlier studies, financial leverage disturbs ultimate Operating profitability of any organization. The key purpose of this research is to explore the Influence on firms' profitability and risk caused by financial leverage. Profitability is very important part of any business; debt to asset ratios is negatively disturbed by financial leverage (Wald, 1999). Level of the height of leverage is depend on the amount of fixed cost, high fix cost means organization is using high level of leverage (Archer, 1972). We can explain leverage as usage of rented money as an investment into business and getting a return on this investment. But on the other side a truth exists, it's a very risky way to generate profit because companies with high leverage ratio are also called highly risky firms (Smith, 2002). Relationship between leverage and risk is mostly depends on those variables that put an impact on prices of goods economy wide, if these variables changes then they also effects the prices of goods as well as risk level of firms (Haugen, Talmo and Barnea 1987) while a study draws a conclusion that optimal leverage is a best source to reduce the level of business risk (Raymar, 1991). To measure the influence of financial leverage on shareholders return and market capitalization of automotive industry in India (Pithampur, M.P) was examined. They collect the Model of seven main motorized public businesses. The study enclosed five years duration (2006-07 to 2010-11). Results determine that there is no relationship among financial leverage and shareholders returns as well as market capitalization (Totala K Navindra; Pachori Sachchidanand, 2012). When fixed expenditures are compared with the amount which is always fluctuating such as sales (base value) of any organization, then result would not match the fraction association to that base value. This concept is normally recognized as the operating leverage (Schultz and Schultz, 1972). Firms who are highly profitable their leverage level is always low as compare to low profitable firms because they always prefer to use first their own earnings into business instead of looking for outside capital. Many researches have been directed to check the influence of leverage on profitability of companies. But according to our conclusion outside capital is always low profitable for firms because it make firms liable to pay some extra fixed costs. Performance of a firm can be described by looking at its stock price. Firms 
with high stock price always prefer to issue equity rather than using outside capital (Wessels and Titman, 1988). Companies must reframe their capital structure as well as capacity utilization intended for further ability in future. Financial decisions are actually concerned with the right selection of debt and equity proportion into business model (Virani \& Varsha, 2010). Organizations with small operations are less profitable as compare to large scale organizations (Weiss \& Hall, 1967), (French \& Fama, 1998), and (Li et al. 2012). In terms of financial matters large size organizations and small size organizations are different from each other. Small organizations gives a statement that they get less financial credit as compare to large organizations, this could be a reason for less profitability (Beck, 2008). There is an important relationship between profitability and debt/equity ratio of an organization, another finding is that when organizations try to reduce their risk level there profitability level always increases (Leonard Weiss and Hall, 1967). When company takes debt it pays interest for it and get exemption from tax that's why companies who are highly levered save large amount of tax and generates good corporate income. However as well as level of debt or borrowed money increases company would face a higher burden of interest amount, ultimately company would suffer from default risk which would create greater cost of the debt financing (Myers, 2001). Internal financing could be gathering of finance by issuing companies own stocks into market instead of getting debt from other sources. For issuing companies stocks into market companies need accurate information they should be fully aware that when there stock prices are overpriced, because over priced stocks gives good value, companies should always sell their stock at overpriced value or fair priced value they should never sell on underpriced value (Jang and Tang, 2007). There is positive association between debt ratio and organization growth opportunity. Organization with greater cash flows seemed to use greater debt, though old organizations use higher level of long term and total debt. And operating cash flows of organizations are negatively associated with short term debts. While chances of bankruptcy of an organization are positively associated with long term debts, means higher long term debt could be the cause of bankruptcy of an organization (Dalbor and Upneja, 2002). Leverage has also an impact on shareholders returns and market capitalization. A sample of 7 companies was taken from telecommunication sector to prove this, and at the end findings showed that there is optimistic association among leverage and shareholder return but there is negative association among market capitalization and leverage (Rajni Saini, 2012). Organizations policies about working capital management, size of organization and financial leverage influence the net income level, ROA and ROE of firms (Dr. Khalaf Taani, 2012). There is low level of progressive association between capital structure of a firm and gross profit of a firm but at the same time we found negative association between a firm's capital structure and net profit level. Capital structure also has negative association with ROA and ROI (Pratheepkanth, 2011). Capital structure influences both profitability or we can say performance of firms and risk of firms (Fetherston and Bos, 1993) earlier researchers has the same trust (Modigliani \& Miller, 1963) as well as (Wessel and Titman, 1988). There is always positive association among short term debt ratio to total assets and firm's profitability but negative relationship among long term debt ratio to total assets and firm's profitability (Abor, 2005). A study explained the impact of leverage on profitability in Oil and Gas companies. For this concern panel data of Oil and Gas sector firms was used from 2007 to 2012. Degree of financial leverage (DFL) and degree of operating leverage (DOL) were independent variables, while Return on assets (ROA), return on investment (ROI), return on equity (ROE) and earning per share (EPS) were used as dependent variables. After the completion of regression correlation descriptive analysis study concluded that, there is positive association among DFL and ROA while negative association is among DOL and ROA. It was also mentioned in that study ROI and DFL has opposite association and correspondingly ROI and DOL also has opposite association. There is positive association among DFL, DOL and ROE. As well as we found positive association among EPS and DFL while negative association among EPS and DOL. Ultimate findings were highly leveraged organizations contains lower factor of risk and highly leveraged organizations are highly profitable (Khushbakht Tayyaba, 2013). In general a company's systematic risk must increase with the increases in its (DOL) Degree of operating leverage (Gahlon, 1981). Higher ratio of debt is the cause of positive influence on ROE. Many organizations use debt to influence their profit as well as capital (Vintilla \& Georgeta, 2012). Financial performance do not positively influenced by debt financing because of no debt tax benefit. Firm's value is negatively associated with dividends and positively associated with debts (French and 
Fama, 1998). Large amount of leverage enhances the industry profit rates but it also carries a large amount of risk. If leverage is high it will enhance the level of risk as well as level of profit (Bakar, 1973). When a company takes more debt in reaction it faces high financial risk but on the other hand it will have to pay lower tax on its income. Debt contains worth if an organization generate profit up to that extant which gives a good return to shareholders. Debt is helpful for firms for future planning because interest on debt is predetermined, so when organizations make planning for their desired profit they keep in mind the margin of interest and other costs. Organizations should take debt if the return on debt is greater that the interest on debt (Rhee \& Mandelker, 1984). Organizations that use their own earning in to their business rather than taking debt from other sources are always profitable organizations, because on the amount of debt from outside sources organizations have to pay interest, which will reduce the level of organization profit. Organizations profit can be determined by its stock prices. If an organization have high stock prices then they will not take debt from outside sources, they will prefer to issuance of equity (Titman and Wassels, 1988). Financial leverage has a relationship with organization performance, and organization performance is all about what is the profitability level of an organization. There is positive relationship between profitability level of an organization and organization performance. If performance increases then profitability level also increases if performance decreases then profitability level also decreases (Akinmulegunm, 2012). Profitable businesses that are compared with non-profitable businesses have low borrowing and debt ratio, so we can say that low leverage leads towards high profitable firms and high leverage leads towards low profitable firms (Meyers, 1997). Risk that is linked with the leverage is dependent on the pricing variables economy-wide (Talmo, Haugen, and Barnea, 1987) on the other side Raymar; gave a conclusion of his studies that optimum leverage usually declines with the business risk. $\mathrm{He}$ additionally explains that the firms whose value is low by default they use low level of leverage, because they don't have capacity to bear high level of risk so we can say that the firms with low level of profit or income have low leverage. While stable firms might be highly levered because they have more ability to take greater risks (Raymar, 1991). There is negative relationship between financial leverage and profitability of firms, which means highly profitable firms mostly rely on their internal sources or internal capital for operational financing (Ezeoha, 2008). Usage ratio of leverage in India is increasing day by day because of easy excess to external finance. To check the impact of leverage and adjustment cost on performance of firms a research was conducted in India. And findings of the research shows that adjustment cost has mixed impact from 24 to 54 percent, on the performance of firms. While leverage has negative impact on the performance of firms. And some control variables also have impact on performance of firms (Mahakud and Misra, 2009). Effective risk management is all about exploring new opportunities and avoiding negative economic impacts, and creates a major positive affiliation with performance of firm. Positive performance of firm automatically lower's the level of financial leverage (Anderson, 2009). Capital structure could be define as the mixture of companies short term and long term debts as well as preferred equity and common equity, and capital structure is all about how companies' finance its operations by utilizing its diverse sources of capitals. In Kenya a study was conducted to examine the impact of capital structure on profitability of different companies. 48 different companies were selected which were listed at NSE (Nairobi stock exchange). Time period of study was 1999 to 2004. At the end results of the study show that there is a weak optimistic relationship among profitability of companies and capital structure of companies in Kenya (Munene, 2006). In 2010 a study was conducted on cement sector of Pakistan. After the completion of analysis findings of the study shows that there is significant inverse relationship among financial leverage and profitability of firm. Firms with low leverage have high profitability while firms with high leverage have low profitability. Findings of this study were mostly matched with previous studies such as study of Sheel 1994 as well as study of Soocheong and Eunju 2005. Findings of this study were not matching with some other studies such as study of Stulz and Larry 1995 in which they concluded that there is positive association among financial leverage and profitability of firm. Stulz and Larry selected top 20 companies of Gahan stock exchange and conducted their study on these companies. Debt cost in Ghana is lower as compare to debt cost in Pakistan, which could be the main reason of difference in the results of both studies (Nawaz, Atif and Aamir, 2015). Bata is leading retail firm in India its foot wears are very famous in India. A study was conducted on Bata in India; study purpose was to examine the relationship between leverage and 
profitability of firm. Key variables for this study were ROI, profitability, operating leverage, financial leverage and total leverage. And after the completion of analysis, findings of the research shows that there is positive relationship between financial leverage and ROI as well as operating leverage and ROI. But studies also reveal that Bata is not using optimal level of leverage. So firm should make some changes in its capital structure and should use more equity as well as borrowed money in business to get greater return on investment. More over total leverage of Bata is also correlated with return on investment of Bata, so firm should change its capital structure to enhance shareholders wealth (Ramana, 2014). Lodging industry is an important part of any countries economy, it is considered as an important indicator of profitability. So it's important for managers to find out different ways to enhance profitability level in this industry. Small research was conducted in USA lodging industry to check the influence of leverage on RevPAR and profitability. RevPAR (Revenue per available room) is an important determinant of profitability in hotel industry. 193 lodging firms RevPAR and financial data from 2001 to 2010 were examined. Results of the research showed that there is positive association between lodging firm's longterm debt and RevPAR but there is negative association between RevPAR and revenue. Generally there is inverse relation between debt ratio and growth opportunity but this research shows that there is no relationship between debt ratio and future growth. Research also showed that there is negative association between long-term debts and profitability of lodging firms, and the reason of negative association was use of debt more than optimal level. Means lodging firms were practicing debt more than their maximum usage boundary (Kang, 2011). In bad times there is positive relationship between operating leverage and risk level, while in good time there is negative relationship between operating leverage and risk level (Aquino, 2003). There is no association between operating leverage and systematic risk of Tehran stock exchange listed firms (Kheder Alaghi, 2011). Financial leverage sometimes positively and sometimes negatively associated with financial performance of firms in sugar industry of Pakistan (Fasih Ur Rehman, 2013). In Nigeria after analysis a research concludes that there is positive connection between return on investment, return on assets and return on equity (Nuhu Onimisi and Aliu, 2010). Experimental outcomes of a research show that there is nonlinear relation between debt to total assets and return on equity. When debt to total assets ratio increases it also increasers the return on equity but as it reached to optimum level then return on equity stars to decrease. In Pakistan optimum debt to assets ratio is almost 56 percent for textile sector. This percentage shows that in Pakistan textile firms pays huge amount of their earning as fix cost on debt. Study also showed that return on equity is positively linked with sales growth while firm size has no impact on return on equity (Sana, Heman and Sara, 2015). Outcomes of a study in Sabar Dairy showed positive relationship between return on capital employed (ROCE) and DOL, DFL as well as DTL, but not significant. Study also showed positive relationship between return on equity (ROE) and DOL, DFL as well as DTL, but not significant. Generally it's a significant model. Relationship between ROA and DOL is significantly positive. Relationship between ROA and DFL is negative and relationship between ROA and DTL is positive but not significant. At the end relationship between earning per share (EPS) and DOL, DFL as well as DTL is positive, but not significant. So the overall results conclude that Sabar Dairy has adequate use of degree of operating leverage, degree of financial leverage and degree of total leverage (J. B. Patel, 2014). A study showed that there is inverse association between Degrees of operating leverage and Earning per share, Degrees of financial leverage and Earning per share and Degrees of total leverage and Earning per share. So result concludes that debt usage will enhance the fixed cost expenses and reduce the profitability level of steel companies. If firms want to enhance profitability level then they should reduce the usage of debt in operations (V. Kalpana, 2014). A study examines growth in liquidity variables, growth in the investment opportunities, growth in assets size and growth in profitability. Study made a link of these variables with debt ratio. More over research showed that growing investment opportunities has positive relationship with long-term debt ratio and variable for assets size showed positive association with long-term debt, while assets size has an inverse association with the short-term debt. Research also revealed that liquidity and profitability variables have no relation with change in the debt size (Al Taleb and Al Shubiri, 2011).

\section{Research Gap}

After studying whole literature regarding concerned variables of this research and after analyzing the 
previous studies data researcher found a gap. Past studies shows that leverage have both type of impacts ascendant and descendent, on profitability and risk. Previous studies are from different sectors and different time periods but this study is from SMEs and Commercial sector of Pakistan. That's why it is a unique study. There is no study available in these sectors specifically on this topic. This research determines the impact of operating leverage, financial leverage and combined leverage on different ratios of profitability such as Return on Equity (ROE), Return on Assets (ROA), Return on Sale (ROS) and Gross Margin (GM). This paper also includes the impact of DOL, DFL and DTL on risk exposure. In this research risk is measured by taking standard deviation of ROE.

\section{Methodology}

\subsection{Model Summary}

In this research three variables are used to measure Leverage Degree of Financial Leverage, Degree of Operating Leverage and Degree of Total Leverage. Four variables are used to measure profitability Return on equity, Return on Assets, Return on Sales and Gross Margin while one variable is used to measure Risk and risk is standard deviation of Return on Equity. This research also contains two control variables first one is Sales growth and second one is Sector (Small Enterprises, Medium Enterprises and Commercial Sector). Many researchers have used these variables in their research that's why I am using these variables in my research.

\subsection{Problem Statement}

Problem statement for this paper is "To study the impact of leverage on risk exposure and profitability of SMEs and Commercial sector organizations of Pakistan".

\subsection{Study Objective}

Objective of this study is to check that how much impact leverage puts on risk and profitability level of SMEs and Commercial sector organizations of Pakistan.

\subsection{Model}
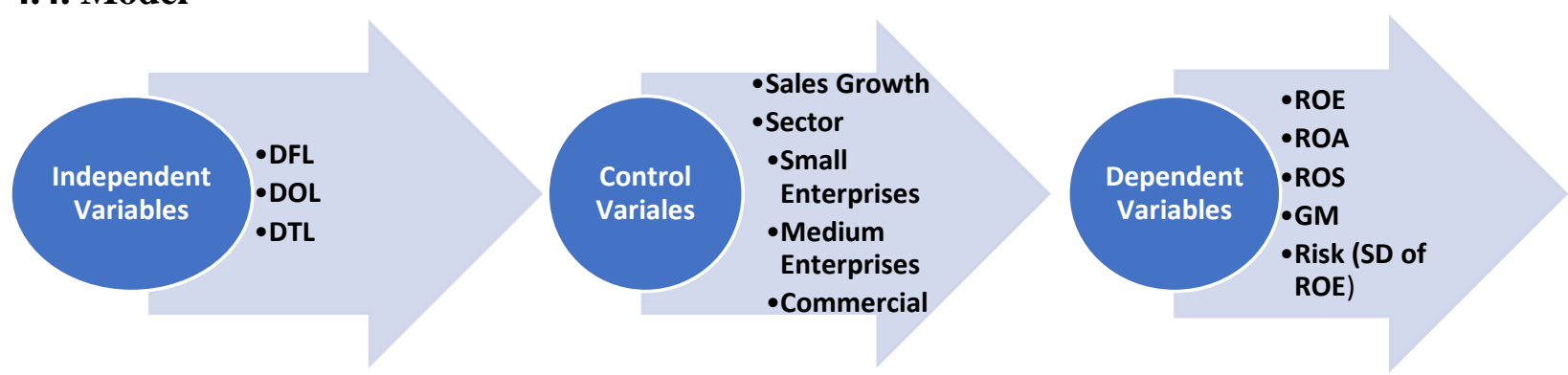

\subsection{Study Significance}

This is a unique study because previously many researchers have conducted research on this type of topics but their sectors of studies were different. This study is just focusing on SMEs and Commercial sector. Previously there is no study available in this sector, on this topic. Small enterprise (SEs) could be defined as, where No. of employees are up to 20 (including contract employees), and annual sales turnover is up to R.s 75 million. Medium enterprise (MEs) could be defined as, where No. of employees are from 21 to 250 for manufacturing and services enterprises while No. of employees from 21 to 50 for trading enterprises, and annual sales turnover is above than R.s 75 million to R.s 400 million.

\subsection{Hypothesis}

Return on Equity:

Return on Assets:

$$
\begin{aligned}
& \mathrm{SG}+\mathrm{SEC}+\beta 1(\mathrm{DFL})+\beta 2(\mathrm{DOL})+\beta 3(\mathrm{DTL})+\mathrm{C} 0 \\
& \mathrm{SG}+\mathrm{SEC}+\beta 1(\mathrm{DFL})+\beta 2(\mathrm{DOL})+\beta 3(\mathrm{DTL})+\mathrm{C} 0 \\
& \mathrm{SG}+\mathrm{SEC}+\beta 1(\mathrm{DFL})+\beta 2(\mathrm{DOL})+\beta 3(\mathrm{DTL})+\mathrm{C} 0 \\
& \mathrm{SG}+\mathrm{SEC}+\beta 1(\mathrm{DFL})+\beta 2(\mathrm{DOL})+\beta 3(\mathrm{DTL})+\mathrm{C} 0 \\
& \mathrm{SG}+\mathrm{SEC}+\beta 1(\mathrm{DFL})+\beta 2(\mathrm{DOL})+\beta 3(\mathrm{DTL})+\mathrm{C} 0
\end{aligned}
$$

Return on Sales:

Gross Margin:

Risk: 


\subsection{Sample Size}

Researcher has used convenience sampling technique to select sample size for research purpose. From all SMEs and Commercial sector organizations of Southern and Central Punjab Pakistan, our selected sample size for research purpose is 61 companies. Further among of these 61 firms 15 firms are small enterprises, 28 firms are medium enterprises and 18 firms are from Commercial sector. Time period for this research is 3 years 2012, 2013 and 2014.

\subsection{Data Collection Approaches}

Secondary data was collected and used in this study, for this purpose data is taken from different companies' annual reports and financial statements, that falls in the category of SMEs and Commercial sector organizations. Data is also taken from the firm's auditors and by make use of our personal sources as well as friends.

\subsection{Empirical Results}

Linear Regression Analysis were used in this research model to get outcomes. Regression analysis were applied to check impact of leverage on risk and profitability with control variable sales growth. Outcomes with control variable sales growth shows that for all three years from 2012 to 2014 there is significant relationship between DFL, DOL, DTL and ROE but it's a weak relationship at $22.7 \%$ and no other dependent variable is showing significant relationship with DFL, DOL and DTL. In commercial sector for all three years from 2012 to 2014 DFL, DOL, DTL are showing strong significant impact on Risk at $60.3 \%$ and no other dependent variable is showing significant relationship with DFL, DOL and DTL. In small enterprises sector for all three years from 2012 to 2014 DFL, DOL, DTL are showing strong significant impact on $\mathrm{ROE}$ at $70.9 \%$, ROA at $66.1 \%$, ROS at $87.1 \%$, GM at $71.4 \%$ and Risk is not showing significant relationship with DFL, DOL and DTL.

Regression results for 2012 commercial sector shows that DOL has strong significant relationship with Risk at $74 \%$ while no other dependent variable is showing significant relationship with DFL, DOL and DTL. Regression results for 2012 medium enterprises sector DOL is showing weak significant relationship with Risk at $22 \%$ while no other dependent variable is showing significant relationship with DFL, DOL and DTL. And regression results for 2012 small enterprises sector DFL, DOL, DTL are showing strong significant impact on ROE at $70.6 \%$, ROA at $69.5 \%$, ROS at $92.9 \%$, GM at $72.8 \%$ and Risk is not showing significant relationship with DFL, DOL and DTL.

Regression results for 2013 shows that DOL and DTL have weak significant relationship with ROE at 12.9\%. Regression results for 2013 commercial sector DFL, DOL, DTL are showing strong significant impact on Risk at $41.3 \%$. And regression results for 2013 small enterprises sector DFL, DOL, DTL are showing strong significant impact on ROE at $53.5 \%$, ROA at $47.4 \%$, ROS at $70.1 \%$, GM at $68.5 \%$ and Risk is not showing significant relationship with DFL, DOL and DTL.

Regression results for 2014 commercial sector DFL, DOL, DTL are showing strong significant impact on Risk at $63.4 \%$ while no other dependent variable is showing significant relationship with DFL, DOL and DTL. Regression results for 2014 medium enterprises sector DFL, DOL, DTL are showing weak significant impact on GM at 39.7\% while no other dependent variable is showing significant relationship with DFL, DOL and DTL. And regression results for 2014 small enterprises sector DFL, DOL, DTL are showing strong significant impact on ROE at $87.9 \%$, ROA at $82.4 \%$, and GM at $69.9 \%$ while ROS and Risk are not showing significant relationship with DFL, DOL and DTL.

Table 4.1 Outputs Summary With Control Variable-Sales Growth

\begin{tabular}{|l|l|l|l|l|l|l|}
\hline \multirow{2}{*}{ Sector } & \multirow{2}{*}{ Year } & \multicolumn{4}{|l|}{ Dependent Variable's Values of R Square } \\
\cline { 3 - 7 } & & ROE & ROA & ROS & GM & RISK \\
\hline
\end{tabular}




\begin{tabular}{|l|l|lllll|}
\multirow{5}{*}{ Small Enterprises } & 2012 & $70.6 \%$ & $69.5 \%$ & $92.9 \%$ & $72.8 \%$ & - \\
& 2013 & $53.5 \%$ & $47.4 \%$ & $70.1 \%$ & $68.5 \%$ & - \\
& 2014 & $87.9 \%$ & $82.4 \%$ & - & $69.9 \%$ & - \\
\cline { 2 - 7 } & $2012-2014$ & $70.9 \%$ & $66.1 \%$ & $87.1 \%$ & $71.4 \%$ & - \\
\hline \multirow{3}{*}{ Medium } & 2012 & - & - & - & - & $22.0 \%$ \\
& 2013 & - & - & - & - & - \\
\hline \multirow{5}{*}{ Commerprises } & 2014 & - & - & - & $39.7 \%$ & - \\
\cline { 2 - 7 } Organizations & $2012-2014$ & - & - & - & - & - \\
& 2012 & - & - & - & - & $74.0 \%$ \\
& 2013 & - & - & - & - & $41.3 \%$ \\
\cline { 2 - 7 } & 2014 & - & - & - & - & $63.4 \%$ \\
\cline { 2 - 7 } & $2012-2014$ & - & - & - & - & $60.3 \%$ \\
\hline \multirow{5}{*}{ All Sectors } & 2012 & - & - & - & - & - \\
& 2013 & $12.9 \%$ & - & - & - & - \\
& 2014 & - & - & - & - & - \\
\cline { 2 - 7 } & $2012-2014$ & $22.70 \%$ & - & - & - & - \\
\hline
\end{tabular}

\section{Conclusions}

Impact of Leverage on Risk and Profitability in SMEs and Commercial sector is a study that has not been attempted previously in Pakistan and this challenge has been taken up on a small sample for this study. Data of 61 sampled firms was collected from 2012 to 2014. Key variables for this research are leverage, profitability and risk. Leverage is independent variable in this research and leverage is measured by DOL, DFL and DTL. Profitability and Risk are dependent variables, profitability is measured by ROE, ROA, ROS, GM and Risk is measured by standard deviation of ROE. Causal research design is used in this research to check the effect of independent variables on dependent variables. Further this research explore the effect of independent variables on dependent variables in three different sectors small enterprises sector, medium enterprises sector and commercial sector for three different years 2012, 2013 and 2014 separately. Moreover, this research also determines combined effect of leverage on risk and profitability for all three years from 2012 to 2014 for all three sectors.

Outcomes of 2012 regression analysis with control variable sales growth showed that in commercial sector DOL has strong significant relationship with risk and in medium enterprises sector DOL has weak significant relationship with risk. Results are matched with previous study of (Rhee and Mandelker, 1984). While in small enterprises sector leverage is showing strong significant relationship with all profitability variables ROE, ROA, ROS and GM (Tayyaba, 2013). Outcomes of 2013 regression analysis with control variable sales growth showed that DOL and DTL have weak significant relationship with ROE (Vintilla \& Georgeta, 2012). In 2013 commercial sector leverage is showing significant relationship with risk while in small enterprises sector leverage is showing strong significant relationship with all profitability variables ROE, ROA, ROS and GM same as it showed in 2012 (Bakar, 1973). Outcomes of 2014 regression analysis with control variable sales growth showed that in commercial sector leverage have strong significant relationship with risk. In medium enterprises sector leverage is showing very weak significant relationship with GM while in small enterprises sector leverage is showing very strong significant relationship with profitability variables ROE, ROA and GM. Results are almost similar to previous study of (Onimisi and Aliu, 2010). And outcomes of combined regression analysis for all three years and all three sectors with control variable sales growth showed weak significant relationship between leverage and ROE. In commercial sector from 2012 to 2014 leverage is showing strong significant relationship with risk while in small enterprises sector from 2012 to 2014 leverage is showing strong significant relationship with all profitability variables ROE, ROA, ROS and GM same as it showed 
in 2012 and 2013 (Patel, 2014). And in medium sector from 2012 to 2014 leverage is showing insignificant relationship with risk and profitability both (Navindra and Sachchidanand, 2012).

So researcher draws a conclusion that overall leverage has weak significant impact on profitability of firms in SMEs and commercial sector and has no significant impact on risk of firms in SMEs and commercial sector. But if we talk about results sector wise then leverage has a strong significant relationship with Risk in commercial sector and leverage has very strong significant relationship with profitability of firms in small enterprises sector while leverage has no impact on risk and profitability in medium enterprises sector. On the whole because of weak impact of leverage on risk and profitability I conclude that there could be some other factors those have strong impact on profitability and risk which are not part of this research. There could be another reason, Mostly in Small, Medium and Commercial sector organizations owners prefer equity based financing rather than debt based financing that's why this study is showing low significant relationship between risk, profitability and leverage.

\section{References}

Abel Ebel Ezeoha (2008), Firm size and corporate financial leverage choice in a developing economy: Evidence from Nigeria. The Journal of Risk Finance, 30, PP: 351-364.

Abor, J. (2005), the effect of capital structure on profitability: empirical analysis of listed firms in Ghana. Journal of Risk Finance, 6(5), PP: 438-445.

ALIU, Onimisi, N. (2010), "Effect of capital structure on the performance of quoted manufacturing firms in Nigeria".

Andersen, T. J. (2009), Effective risk management outcomes: exploring effects of innovation and capital structure, Journal of Strategy and Management, (4)2, PP: 352 - 379. IJRIME Volume2, Issue12 (December-2012) ISSN: 2249-1619.

Aquino Rodolfo. (2003), "Corporate Diversification and Firm Value." UP College of Business Administration, Discussion Paper no. 0306.

Stephen H. and Charles A. D'Ambrosio (1972), Business finance: Theory and Management, second ed., Macmillan, New York.

Atif Salman (2015), Impact of Financial Leverage on Firms' Profitability: An Investigation from Cement Sector of Pakistan, Research Journal of Finance and Accounting, (Vol 6), ISSN: 2222-2847, PP: 75-77.

Baker, S. H. (1973), Risk, Leverage and Profitability: An Industry Analysis. The Review of Economics and Statistics, 55(4), PP: 503- 507.

Barnea, A.R. Haugen; and E.Talmor (1987), Debt and taxes: A Multiple investigation. Journal of Banking and Finance, 11, PP: 79-97.

Bos, T., \& Fetherston, T.A. (1993), Capital Structure Practices on the Pacific Rim. Research in International Business and Finance, Vol. 10 PP: 53-66.

Dr. J. B. Patel (2014), Impact of Leverage on Profitability: A Study of Sabar Dairy, International Multidisciplinary Research Journal, ISSN: 2349-7637.

Dr. M Ramana Kumar (2014), an Empirical Study on Relationship between Leverage and Profitability in Bata India Limited, International Journal of Advance Research in Computer Science and Management Studies, (Vol 2), ISSN: 2321-7782, PP: 01-02.

Eunju Yoon \& SooCheong Jang (2005), the effect of financial leverage on profitability and risk of restaurant firms. The Journal of Hospitality Financial Managements, 13, PP: 200-210.

Fama, E.F., \& French, K.R. (1998), Taxes, Financing Decisions, and Firm Value, Journal of Finance, 53(3), PP; 819-843.

Georgeta, Vintilla and Florinita Duce (2012), "The Impact of Financial Leverage on Profitability Study of Companies listed in Bucharest Stock Exchange”, 'Ovidius' University Annals, Economic Science Series, Vol 12(1), PP: 1741-44.

Hall, M., and L.Weiss (1967), Firm size and profitability, Technology, Profit Risk, and Assessments of this review, 49, PP: 319-331. 
Hyun Oh Kang, B.S. (2011), Impact of Financial Leverage on Profitability in Lodging Companies: An Analysis on RevPAR, Texas Tech University, and PP: 08-12.

Kheder Alaghi (2011), Operating leverage and systematic risk, African Journal of Business Management Vol.6 (3), ISSN: 1993-8233, PP: 1095-1099

Khushbakht Tayyaba (2013), "Leverage” An Analysis and Its Impact On Profitability With Reference To Selected Oil And Gas Companies, International Journal of Business and Management Invention, PP: 50-52

Larry, L. E. Ofek \& R. Stulz (1995), Leverage investment and firm growth. Journal of Financial Economics, 40, PP: 3-29.

Mahakud, J., \& Misra, A.K. (2009), Effect of Leverage and Adjustment Costs on Corporate Performance: Evidence from Indian Companies. Journal of Management Research, 9(1), PP: 35-42.

Mandelker G, Rhee S (1984), the Impact of Degrees of Operating and Financial Leverage on Systematic Risk of Common Stock, J. Finance. Quant. Anal., PP: 45-57.

Modigliani, F., \& M. Miller. (1963), corporate income taxes and the cost of capital: A correction. American Economic Review, Vol.53, PP: 443-53.

Munene, K. H. (2006), Impact of Profitability on Capital Structure of Companies listed at the Nairobi Stock Exchange. MBA Research Project, University of Nairobi

Myers, S. C. (2001), Capital Structure. Journal of Economic Perspectives, 15 (2), PP: 81-102.

Nawaz Ahmad, Atif Salman and Aamir Firoz (2015), Impact of Financial Leverage on Firms' Profitability: An Investigation from Cement Sector of Pakistan. Research Journal of Finance and Accounting, ISSN 2222-1697 (Paper) ISSN 2222-2847 (Online) Vol.6.

Pachori Sachchidanand CA, Totala K Navindra Dr. (2012), Influence of Financial Leverage on Shareholders Return and Market Capitalization: A Study of Automotive Cluster Companies of Pithampur, (M.P.), India

Pratheepkanth, P. (2011), "Capital structure and financial performance evidence from selected business companies in Colombo stock exchange Sri Lanka", Vol. - II, Issue -2.

Saini, R. (2012), "Impact of financial leverage on shareholders returns and market capitalization: empirical evidence of telecommunication sector companies, India", International Journal of Research in IT, Management and Engineering. Volume2, Issue12.

Sana Tauseef, Heman Das Lohano and Sara Ashfaq Khan (2015), Effect of Debt Financing On Corporate Financial Performance: Evidence from Textile Firms in Pakistan, Department of Economics and Finance, Institute of Business Administration, (IBA) Karachi, Pakistan.

Syed Shah Fasih Ur Rehman (2013), "Relationship between Financial Leverage and Financial Performance: Empirical Evidence of Listed Sugar Companies of Pakistan", Global Journal of Management and Business Research Finance, ISSN: 2249-4588, PP: 34-36.

Sheel, A. (1994), Determinants of capital structure choice and empirics on leverage behavior: A comparative analysis of hotel and manufacturing firms. Hospitality Research Journal, 17, PP: 316.

Taani, K. (2012), "Impact of Working Capital Management Policy and Financial Leverage on Financial Performance: Empirical evidence from Amman Stock Exchange - listed companies", International Journal of Management Sciences and Business Research, Vol. 1, Issue 8. (ISSN: 2226 - 8235).

Taleb, G. A., \& AL-Shubiri, F. N. (2011). Capital structure decisions and debt maturity structure: an empirical evidence from Jordan, Journal of Commerce.

Tang, C. H. H \& Jang, S. S. (2007), Revisit to the determinants of capital structure: A comparison between lodging firms and software firms. Hospitality Management, 26, PP: 175-187.

Titman, S., \& Wessels, R. (1988), the Determinants of Capital Structure Choice. The Journal of Finance, 43, P: 1-19.

Upneja, A. \& Dalbor, M. C. (2002), Factors Affecting the Long-Term Debt Decision of Restaurant Firms, Journal of Hospitality \& Tourism Research

V. Kalpana (2014), A Study on Leverage Analyses and its Impact on Profitability of Select Steel Companies Traded in BSE, Volume: 4, Issue: 10. October 2014, ISSN - 2249-555X.

Varsha, Virani (2010), "Impact of Leverage on Profitability of Pantaloon Retail India Ltd." Advances in 
Management, Vol 3(8), PP: 52-59.

Wald (1999), how firm characteristics affect capital structure: An international comparison, journal of financial research, PP: 161-187. (Journal of financial research 1999 outstanding paper award) 
